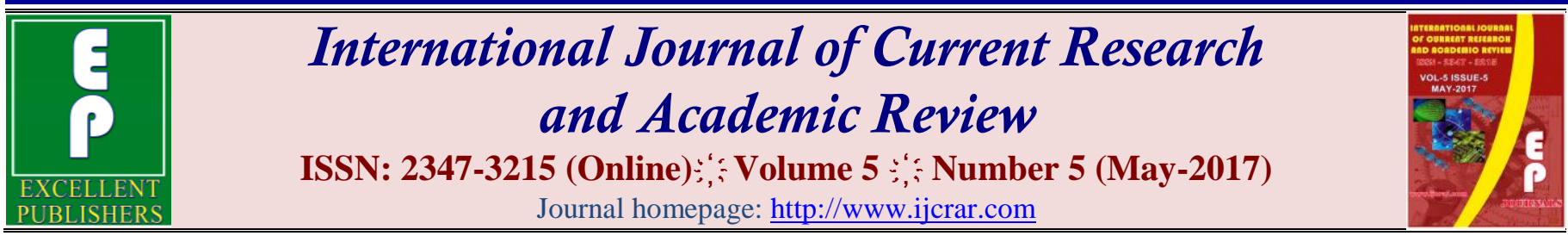

doi: https://doi.org/10.20546/ijcrar.2017.505.015

\title{
Phosphatase Activity during Vermicomposting of Different Substrates Using Perionyx ceylanensis
}

\author{
J. Devi ${ }^{1}$ and M. Prakash ${ }^{2 *}$ \\ ${ }^{I}$ Research \& Development Centre, Bharathiar University, Coimbatore-641 046, Tamil Nadu, India \\ ${ }^{2}$ Department of Microbiology, Kanchi Shri Krishna College of Arts and Science, Kilambi, Kancheepuram-631 551, \\ Tamil Nadu, India \\ *Corresponding author
}

\begin{tabular}{|c|c|}
\hline Abstract & Article Info \\
\hline \multirow{6}{*}{$\begin{array}{l}\text { Twenty one days pre-decomposed substrates, teak leaf litter (TLL), paper mill sludge } \\
\text { (PMS) and pressmud (PM) in combination with cowdung was subjected to } \\
\text { vermicomposting using the epigeic earthworm, Perionyx ceylanensis for } 60 \text { days. The } \\
\text { phosphatase enzymes - acid phosphase and alkaline phosphase were analysed in } \\
\text { vermibed substrates of TLL, PMS and PM on } 0,15,30,45 \text { and on } 60^{\text {th }} \text { day of } \\
\text { vermicomposting. The activity of the acid and alkaline phosphatase enzymes were } \\
\text { found to be increased in all the vermibed substrates towards the end of } \\
\text { vermicomposting. The results also showed significant variation }(p=0.05) \text { in } \\
\text { phosphatase enzyme activities with respect to different vermibed substrates. }\end{array}$} & $\begin{array}{l}\text { Accepted: } 28 \text { March } 2017 \\
\text { Available Online: } 20 \text { May } 2017\end{array}$ \\
\hline & Keywords \\
\hline & Perionyx ceylanensis \\
\hline & Phosphatase activity \\
\hline & \\
\hline & \\
\hline
\end{tabular}

\section{Introduction}

Earthworm casts are stable structures characterized by higher nutrients contents, microbial biomass and activity than uningested material, thereby constituting hotspots of microbial-driven processes such as nutrient release or nutrient immobilization and decomposition. The results obtained by Aira et al., (2005) showed that ageing favoured the release of microbial retained $\mathrm{N}$, mainly as dissolved organic nitrogen, and which was associated with the high protease activity observed. In addition, found an age-dependent decrease in both microbial biomass and activity, which were stimulated by the addition of glucose.

Soil phosphatases hydrolyse phosphate and make them available to higher plants. Thus phosphatase activity measurement provides an index of potential availability of phosphate to plants in soil. Marshall et al., (1981) attribute the increase in available $\mathrm{P}$ in the earthworm faeces to physical breakdown of the plant material and trituration of the mineral fraction for which the presence in casts of an increased proportion of fine particles provides support.

Acid phosphatase activity in earthworm is due to microorganisms and alkaline phosphatase is regarded as typical of earthworms (Lee, 1985).

The expression of alkaline phosphatase in developing embryo and mature stages of the earthworm, Eisenia andrei was investigated by Park et al., (1996). The embryonic stages examined in this study appeared to have only one slow-moving form of alkaline phosphatase which had a different mobility from the intestinal alkaline phosphatases of the mature worm, suggesting 
that intestinal alkaline phosphatases of embryos may be different from mature forms.

It has been reported that cellulase, amylase, invertase, protease and phosphatase activities in pressmud and vermicasts of fresh, 15- and 30-day-old casts of Lampito mauritii and Eudrilus eugeniae decreased considerably with reference to ageing (Parthasarathi and Ranganathan, 2000).

Earthworm casts have been shown to have higher phosphatase activities than uningested soil due to increases in inorganic $\mathrm{P}$, which is produced via the mineralization of organic $\mathrm{P}$, and an increased microbial biomass and high phosphate production by microorganisms (Tiwari et al., 1989).

Benitez et al., (2005) reported that $\beta$-glucosidase, phosphatase and urease activities of the organic extracts either increased or remained the same after a nine month period of vermicomposting, thus suggesting that the humus enzyme complexes resisted microbial and earthworm attack.

It is known that humus immobilised enzymes also remain active in soil environments, reactivating the nutrient cycles in soil. The use as amendments of vermicomposted olive cake, alone or when mixed with biosolids, could be a good alternative to reactivate the $\mathrm{C}$, $\mathrm{P}$ and $\mathrm{N}$-cycles in degraded soils for regeneration purposes. Similar cases have also been reported for various enzymes during vermicomposting process. In the present study, the phosphatase enzyme activities during different intervals of vermicomposting of three different substrates have been studied.

\section{Materials and Methods}

Teak leaf litter (TLL) was collected from an agroform near Kanchipuram. The paper mill sludge (PMS) was procured from a private mill near Kanchipuram. The filter mud or pressmud (PM) was collected from Cheyyar Co-operative Sugar Mills Ltd., located in Thenthandalam, Anakkayur, Thiruvannamalai District, Tamil Nadu.

The cowdung was collected from nearby cattle sheds in fresh form and allowed to stabilize for one week and used for the study. The organic substrates, TLL, PMS and PM were subjected to initial decomposition in rectangular draining cement tanks of $75 \mathrm{~cm} \times 60 \mathrm{~cm} \times 45 \mathrm{~cm}$ size by sprinkling water, regular mixing and turning of the substrates for 20 days. The earthworm, Perionyx ceylanensis Mich. was mass multiplied in cow dung and used for vermicomposting studies. Based on the earlier studies Karmegam and Daniel (2009) and Prakash and Karmegam (2010), the ratio of organic substrate mix, i.e., 1:1 (50:50) proportion on dry weight basis was used in the present study. Accordingly, the pre-decomposed organic substrates were mixed with cowdung in 1:1 ratio on dry weight basis, transferred to vermibeds and moistened to hold $60-70 \%$ moisture content. The vermicomposting studies were carried out for 60 days using $P$. ceylanensis in three replicates twice under controlled conditions. On $0,15,30,45$ and $60^{\text {th }}$ day, the phosphatase enzymes viz., alkaline phosphatase and acid phosphatase were estimated from the vermicompost filtrates using the method of Lowry et al., (1954). The results were statistically compared using Duncan's multiple range test.

\section{Results and Discussion}

The results of the present study are given in Tables 1 and 2. The acid phosphatase enzyme activity ranged from $0.083-0.154 \mathrm{~m}$ moles of phenol liberated / 1 during vermicomposting of three different combinations of vermibed substrates (Table 1). During the progression of vermicomposting days, the acid phosphatase activity showed increasing trend in teak leaf litter + cowdung, paper mill sludge + cowdung and pressmud + cowdung vermibed combinations with a significant $(p=0.05)$ increase. The acid phosphate enzyme activity showed higher levels than in the initial level significantly as indicated in Table 1. The activity of the level of acid phosphatase enzyme between substrates was also found to be significant (Fig. 1).

The alkaline phosphatase activities during vermicomposting of three different combinations of substrates are given in Table 2. In teak leaf litter + cowdung vermibed combination, the alkaline phosphatase activity was $0.043,0.057,0.069,0.073$ and $0.087 \mathrm{~m}$ moles of phenol liberated/1 respectively in 0,15 , 30,45 and $60^{\text {th }}$ day of vermicomposting. The highest activity of alkaline phosphatase enzyme was 0.051 , 0.068, 0.073, 0.086, $0.098 \mathrm{~m}$ moles of phenol liberated/1 respectively in $0,15,30,45$ and $60^{\text {th }}$ day of vermicomposting of pressmud + cowdung vermibed substrate (Table 2). The activity of alkaline phosphatase enzyme was found to increase towards the progression of vermicomposting which is significant at $p=0.05$. The activity of the level of acid phosphatase enzyme between substrates was also found to be significant (Fig. 1). 
Fig.1 Comparison of acid phosphatase activity during vermicomposting of three different substrates. Enzyme activity is expressed as $\mathrm{m}$ moles of phenol liberated / 1 . The same alphabets between substrates are not significantly different at $p=0.05$ level. Error bars indicate \pm SEM

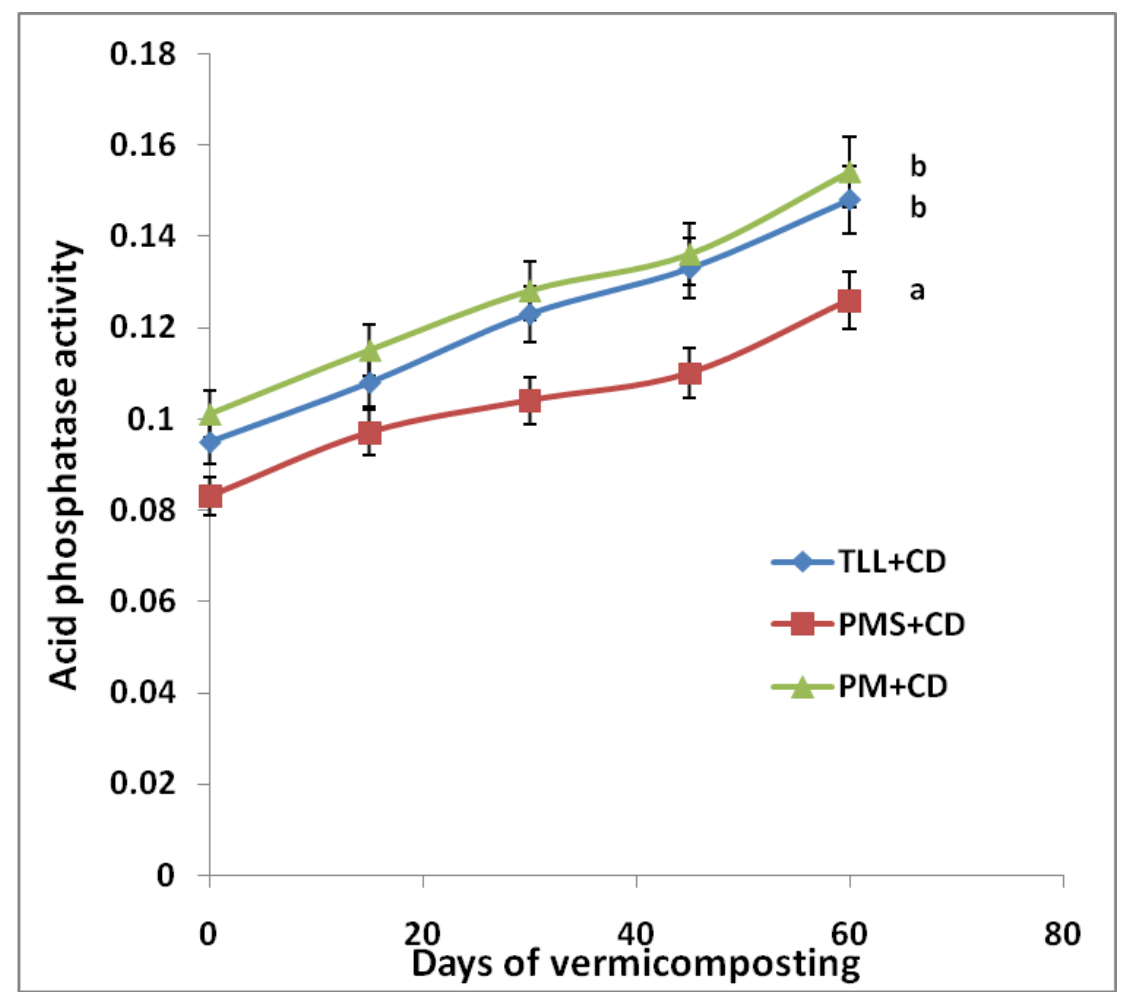

Fig.2 Comparison of alkaline phosphatase activity during vermicomposting of three different substrates. Enzyme activity is expressed as $\mathrm{m}$ moles of phenol liberated / 1 . The same alphabets between substrates are not significantly different at $p=0.05$ level. Error bars indicate \pm SEM

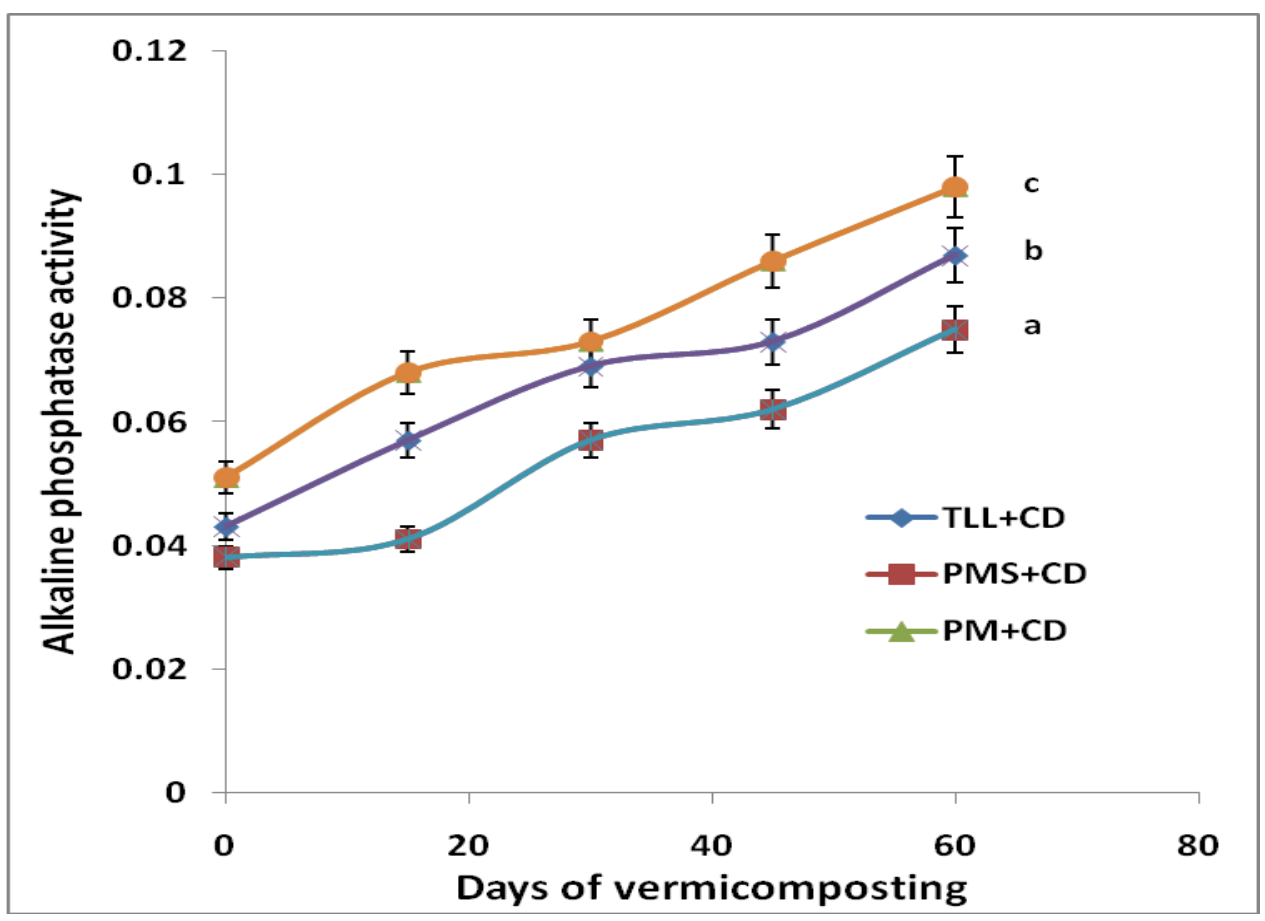


Table.1 Acid phosphatase* activity during vermicomposting of different vermibed substrates using Perionyx ceylanensis

\begin{tabular}{|c|c|c|c|c|c|}
\hline \multirow{2}{*}{ Vermibed substrate } & \multicolumn{5}{|c|}{ Days of vermicomposting } \\
\hline & 0 & 15 & 30 & 45 & 60 \\
\hline Teak leaf litter + cowdung & $0.095^{\mathrm{a}}$ & $0.108^{\mathrm{b}}$ & $0.123^{\mathrm{c}}$ & $0.133^{\mathrm{d}}$ & $0.148^{\mathrm{e}}$ \\
\hline Paper mill sludge + cowdung & $0.083^{\mathrm{a}}$ & $0.097^{\mathrm{b}}$ & $0.104^{\mathrm{bc}}$ & $0.110^{\mathrm{c}}$ & $0.126^{\mathrm{d}}$ \\
\hline Pressmud + cowdung & $0.101^{\mathrm{a}}$ & $0.115^{\mathrm{b}}$ & $0.128^{\mathrm{c}}$ & $0.136^{\mathrm{c}}$ & $0.154^{\mathrm{d}}$ \\
\hline
\end{tabular}

(* $\mathrm{m}$ moles of phenol liberated / 1). The values with same alphabets between composting days are significantly different at $p=0.05$ level.

Table.2 Alkaline phosphatase* activity during vermicomposting of different vermibed substrates using Perionyx ceylanensis

\begin{tabular}{|c|c|c|c|c|c|}
\hline \multirow{2}{*}{ Vermibed substrate } & \multicolumn{5}{|c|}{ Days of vermicomposting } \\
\hline & 0 & 15 & 30 & 45 & 60 \\
\hline Teak leaf litter + cowdung & $0.043^{\mathrm{a}}$ & $0.057^{\mathrm{b}}$ & $0.069^{\mathrm{c}}$ & $0.073^{\mathrm{c}}$ & $0.087^{\mathrm{d}}$ \\
\hline Paper mill sludge + cowdung & $0.038^{\mathrm{a}}$ & $0.041^{\mathrm{a}}$ & $0.057^{b}$ & $0.062^{b}$ & $0.075^{\mathrm{c}}$ \\
\hline Pressmud + cowdung & $0.051^{\mathrm{a}}$ & $0.068^{b}$ & $0.073^{b}$ & $0.086^{\mathrm{c}}$ & $0.098^{\mathrm{d}}$ \\
\hline
\end{tabular}

$(* \mathrm{~m}$ moles of phenol liberated / 1$)$. The values with same alphabets between composting days are not significantly different at $p=0.05$ level.

The increase of enzyme activities in vermibed substrates is mainly due to the increased surface area during fragmentation and decomposition, and increased microbial activity which has been reported by earlier workers (Tiwari et al., 1989). While studying the effect of different organic wastes, and microbial inoculants on chemical and biochemical properties of vermicompost, Pramanik et al., (2007) reported that cow dung was the best substrate for vermicomposting and the application of lime $(5 \mathrm{~g} / \mathrm{kg})$ and inoculation of microorganisms increased the nutrient content in vermicompost and also phosphatases and urease activities.

Thus phosphatase activity measurements provide an index of potential availability of phosphate in soil (Mansell et al., 1981). Pramanik et al., (2007) suggested that vermicomposting increased humic acids content and acid phosphatase activity in organic substrates and microbial inoculation further enhanced the rate of humification and enzyme activity. Although humic acids content in different microorganism-inoculated vermicomposts were statistically at par, acid phosphatase activity in these treatments was significantly $(p<0.05)$ different. The zymogram revealed that two isozymes of acid phosphatase (group II and group III) were present in all vermicompost samples and higher acid phosphatase activity in fungi-inoculated vermicomposts might be due to the presence of an additional isozyme (group I) of acid phosphatase. Enhancement of the enzyme activity was probably due to the additional source of organic matter and nutrients supplied with a sludge with stimulated microbial activity and phosphatase activity (Bonmati et al., 1985). The results of the present study revealed that the activity of acid and alkaline phosphatase activities significantly increased with composting days and the substrate combination also showed significant variation.

\section{References}

Aira M, Monroy F, Domínguez J (2005) Ageing effects on nitrogen dynamics and enzyme activities in casts of Aporrectodea caliginosa (Lumbricidae). Pedobiol. 49, 467-473.

Benitez E, G Saniz, Nogales R (2005). Hydrolytic enzyme activities of extracted humus substances during the vermicomposting of a lignocellulosic olive waste. Biores. Technol., 96: 785-790.

Karmegam, N. and Daniel, T. (2009). Investigating efficiency of Lampito mauritii (Kinberg) and Perionyx ceylanensis Michaelsen for vermicomposting of different types of organic substrates. Environmentalist, 29: 287-300.

Lee KE (1985) Earthworms - Their Ecology and Relationships with Soils and Land Use, Academic Press, New York, 411 pp.

Lowry, O.H., Roberts, N.R., Mei-Ring, W. U., Hixon, W.S., Crawford, E.J., 1954. Phosphatase studiesAcid and alkaline phosphatase. J. Biol. Chem. 207, 19-37.

Marshall, G.P., Syers, J.K. and Gregg, P.E.H. (1981). Plant availability of phosphorus in dead herbage 
ingested by surface casting earthworms. Soil Biol. Biochem., 13: 163-167.

Park SC, Parka HW, Smith TJ (1996) Expression of alkaline phosphatases during embryonic development and immature stages of the earthworm, Eisenia andrei. Soil Biol. Biochem. 28, 579-582.

Parthasarathi K, Ranganathan LS (2000) Aging effect on enzyme activities in pressmud vermicasts of Lampito mauritii (Kinberg) and Eudrilus eugeniae (Kinberg). Biol. Fertil. Soils 30, 347-350.

Prakash, M. and Karmegam, N. (2010). Vermistabilization of pressmud using Perionyx ceylanensis Mich. Bioresour. Technol., 101: 84648468.

Pramanik, P., Ghosh, G.K., Ghosal, P.K., Banik, P., 2007. Changes in organic $-\mathrm{C}, \mathrm{N}, \mathrm{P}$ and $\mathrm{K}$ and enzymatic activities in vermicompost of biodegradable organic wastes under liming and microbial inoculants. Bioresour. Technol. 98, 24852495.

Tiwari SC, Tiwari BK, Mishra RR (1989) Microbial population, enzyme activities and nitrogenphosphorus-potassium enrichment in earthworm casts and in the surrounding soil of a pineapple plantation. Biol. Fertil. Soils 8, 178-182.

\section{How to cite this article:}

Devi J. and Prakash M. 2017. Phosphatase Activity during Vermicomposting of Different Substrates Using Perionyx ceylanensis. Int.J.Curr.Res.Aca.Rev. 5(10), 106-110. doi: https://doi.org/10.20546/ijcrar.2017.505.015 